\title{
Net flux of nutrients across the rumen wall of lactating dairy cows as influenced by dietary supplements of folic acid ${ }^{1}$
}

\author{
C. L. Girard, ${ }^{2}{ }^{2}$ C. Benchaar, ${ }^{*}$ J. Chiquette, ${ }^{*}$ and A. Desrochers $\dagger$ \\ *Agriculture et Agroalimentaire Canada, Centre de recherche et développement sur le bovin laitier et le porc, Sherbrooke, Québec, J1M 1Z3, \\ Canada \\ †Faculté de Médecine Vétérinaire, Université de Montréal, St-Hyacinthe, Québec, J2S 7C6, Canada
}

\begin{abstract}
The objective of the present study was to determine whether a dietary supplementation of folic acid, at levels used in our previous studies, would affect ruminal fermentation and the net flux of nutrients across the rumen wall of lactating dairy cows. Approximately 4 wk after calving, 5 lactating multiparous cows were surgically equipped with a ruminal cannula, an ultrasonic flow probe around the right ruminal artery, and indwelling catheters in the right ruminal vein and the ileocolic artery. Cows were fed a total mixed ration served in 7 equal meals per d (i.e., every $3.4 \mathrm{~h}$ ). The experimental design was an unbalanced crossover arrangement with 3 periods of 4 wk each. The vitamin supplement, incorporated in equal amounts into each meal, was supplied at 0,3 , or $6 \mathrm{mg}$ of folic acid per $\mathrm{kg}$ of BW per d. During the last week of each experimental period, blood samples were taken simultaneously from the 2 catheters every 30 min and rumen fluid was collected every 60 min during 2 consecutive meal intervals. Dietary supplementation with folic acid had no effect on milk production $(27.2 \pm 1.3 \mathrm{~kg} / \mathrm{d})$ or DMI $(19.9 \pm$ $0.7 \mathrm{~kg} / \mathrm{d}$ ), but milk concentrations and yields of total solids, fat, and protein increased linearly with increasing doses of folic acid ingested. Concentrations of folates in rumen fluid and arterial plasma, averaged over time, increased linearly with the dose of folic acid ingested but the net flux of folates across the rumen wall was not different from zero. Concentrations of butyrate in ruminal fluid decreased quadratically with the daily supply in folic acid. Dietary supplements of folic acid had no effect on $\mathrm{pH}$ and osmolality of ruminal fluid, nor on ruminal concentrations of lactate, ammonia, acetate, or propionate, total VFA, or microbial counts. The uptake of urea- $\mathrm{N}$ by the rumen wall tended to increase quadratically with the dose ingested but net fluxes of other nutrients were not affected by treatments. These
\end{abstract}

Received May 4, 2009

Accepted July 28, 2009

${ }^{1}$ Contribution no. 1019.

${ }^{2}$ Corresponding author: Christiane.Girard@agr.gc.ca results suggest that the effects of folic acid supplements on lactational performance cannot be explained by effects on rumen metabolism.

Key words: dairy cow, rumen, folic acid

\section{INTRODUCTION}

Apparent ruminal synthesis of folates in dairy cows ranges from 13 to $21 \mathrm{mg} / \mathrm{d}$ (Santschi et al., 2005a; Schwab et al., 2006). Despite this supply from ruminal microflora, dietary supplements of folic acid increase milk and milk component yields in dairy cows (Girard and Matte, 1998; Graulet et al., 2007). Results from in vitro studies show that folic acid supplementation could affect bacterial growth. Hall et al. (1955) found that supplementary folic acid increased cellulose digestion by mixed cultures and, in Slyter and Weaver (1977), Ruminococcus flavefaciens was reported to have folate requirements. In a study by Wejdemar (1996), addition of folic acid to clarified rumen fluid promoted growth of Butyrivibrio fibrisolvens TC33 and its utilization of ammonia. However, in steers fed once per day diets based exclusively on timothy hay and barley, a daily dietary supplement of $2 \mathrm{mg}$ of folic acid per $\mathrm{kg}$ of BW, corresponding approximately to $700 \mathrm{mg}$ per d, had limited effect on ruminal fermentation (Chiquette et al., 1993; Girard et al., 1994). Nevertheless, the composition of lactation diets is more complex than the diets studied with steers. The objective of the present study was to determine whether dietary supplementation with folic acid, at levels used in previous studies with dairy cows, would affect ruminal fermentation and the net release or uptake of nutrients by the rumen wall of lactating dairy cows, thus explaining, at least partially, the effects of the vitamin supplements on lactational performance.

\section{MATERIALS AND METHODS}

\section{Cows and Treatments}

Twenty-five days (SD 4) after calving , 5 multiparous lactating cows were surgically equipped with a ruminal cannula and an ultrasonic flow probe (8-mm flow 
Table 1. Ingredients and nutrient composition of the TMR fed to dairy cows

\begin{tabular}{|c|c|}
\hline Item & Value \\
\hline \multicolumn{2}{|l|}{ Ingredient ( $\%, \mathrm{DM}$ basis $)$} \\
\hline Corn silage ${ }^{1}$ & 24.7 \\
\hline Legume-grass silage $^{2}$ & 35.1 \\
\hline Barley & 20.2 \\
\hline Micronized soybean ${ }^{3}$ & 3.6 \\
\hline Distillers grain, wheat & 2.9 \\
\hline Distillers grain, corn & 3.6 \\
\hline Canola meal & 7.4 \\
\hline Calcium carbonate & 0.7 \\
\hline Mineral and vitamin premix ${ }^{4}$ & 1.8 \\
\hline \multicolumn{2}{|l|}{ Nutrient composition } \\
\hline $\mathrm{CP}(\%$ of $\mathrm{DM})$ & 17.8 \\
\hline $\mathrm{RDP}^{5}(\%$ of $\mathrm{CP})$ & 70 \\
\hline $\operatorname{RUP}^{5}(\%$ of $\mathrm{CP})$ & 30 \\
\hline $\mathrm{MP}^{5}(\mathrm{~g} / \mathrm{kg}$ of $\mathrm{DM})$ & 95.8 \\
\hline $\mathrm{ADF}(\%$ of $\mathrm{DM})$ & 25.7 \\
\hline $\mathrm{NDF}(\%$ of $\mathrm{DM})$ & 34.1 \\
\hline $\mathrm{NE}_{\mathrm{L}}^{5}$ (Mcal/kg of DM) & 1.56 \\
\hline
\end{tabular}

${ }^{1}$ Contains $10.5 \pm 0.1 \% \mathrm{CP}, 5.3 \pm 0.1 \%$ soluble protein, $28.8 \pm 0.4 \%$ ADF, $47.6 \pm 1.0 \%$ NDF, $3.2 \pm 0.1 \%$ lignin $(\mathrm{n}=3)$.

${ }^{2}$ Contains $15.9 \pm 1.3 \% \mathrm{CP}, 7.5 \pm 0.7 \%$ soluble protein, $35.4 \pm 1.3 \%$ ADF, $50.4 \pm 2.1 \%$ NDF, $6.7 \pm 0.8 \%$ lignin $(\mathrm{n}=3)$.

${ }^{3}$ Micro-Soya Elite, $40 \%$ CP (Semences Prograin Inc., St-Césaire, Quebec, Canada).

${ }^{4}$ Contains per kg: $135.6 \mathrm{~g}$ of $\mathrm{Ca}, 18.6 \mathrm{~g}$ of $\mathrm{P}, 62.2 \mathrm{~g}$ of $\mathrm{Mg}, 118.0 \mathrm{~g}$ of $\mathrm{Na}, 98.0 \mathrm{~g}$ of Cl, $7.0 \mathrm{~g}$ of K, $7.7 \mathrm{~g}$ of S, $816 \mathrm{mg}$ of Fe, 1,685 mg of Mn, $1,766 \mathrm{mg}$ of $\mathrm{Zn}, 300 \mathrm{mg}$ of $\mathrm{Cu}, 69 \mathrm{mg}$ of I, $27.8 \mathrm{mg}$ of Co, $24.4 \mathrm{mg}$ of Se, 261,930 kIU of vitamin A, 64,930 kIU of vitamin D, and 1,380 kIU of vitamin E.

${ }^{5}$ Calculated according to NRC (2001) model.

probe, R-series, Transonic Systems, Ithaca, NY) installed around the right ruminal artery, approximately 15 to $20 \mathrm{~cm}$ distal to its bifurcation from the coelic artery, according to the surgical method developed for sheep by Rémond et al. (1993). Indwelling catheters (Tygon tubing, i.d. $=0.05 \mathrm{~mm}$, o.d. $=0.09 \mathrm{~mm}$, Norton Performance Plastics, Akron, $\mathrm{OH})$, treated with tridodecylmethylammonium chloride heparin complex $(2 \%$ wt/wt, Polysciences Inc., Warrington, PA), were placed 1 ) in the right ruminal vein with a tip at the level of the probe around the right ruminal artery and 2) in the ileocolic artery. Cows were kept in a tie-stall barn under $16 \mathrm{~h}$ of light per d (0530-2130 h) and were milked twice daily at a 12 -h interval. Care of cows followed the recommended code of practice of Agriculture Canada (1990) and the guidelines of the Canadian Council on Animal Care (1993); surgical procedures were reviewed and accepted by the Institutional Committee on Animal Care of the Dairy and Swine Research and Development Centre (Sherbrooke, Québec, Canada).

Cows had free access to water and feed and were fed a TMR (Table 1) served in 7 equal meals per d (i.e., every $3.4 \mathrm{~h}$ ). Vitamin supplements were incorporated in equal amounts into each meal. Refusals were weighed daily at $1000 \mathrm{~h}$.
The study started $31 \pm 3 \mathrm{~d}$ after the surgery. The experimental design was an unbalanced crossover arrangement with 3 periods of 4 wk each. The treatments were 0,3 , or $6 \mathrm{mg}$ of folic acid per $\mathrm{kg}$ of BW per day (pteroylmonoglutamic acid, Sigma, St. Louis, MO). The doses were chosen according to Girard et al. (2005). At the beginning of the experiment, cows were on average at $56 \pm 4 \mathrm{~d}$ of lactation with an average BW of $574 \pm$ $20 \mathrm{~kg}$.

\section{Feed Analysis}

Silage samples were collected once per week and pooled per period. Only 1 batch of each of the other ingredients, sampled at the beginning of the study, was used during the study. The samples were analyzed for DM, CP, soluble protein (AOAC, 2000), ADF, NDF, and acid-detergent lignin (Ankom200 fiber analyzer, Ankom Technology Corp., Fairport, NY).

\section{Milk Sampling Procedure and Analyses}

Milk production was recorded at each milking. Milk samples were collected at 2 consecutive milkings at the end of each experimental period. Milk composition (DM, fat, $\mathrm{CP}$, and ash) was determined as described by Girard et al. (2005).

\section{Sampling Procedure and Analyses}

During the last week of each experimental period, blood samples were taken simultaneously from the 2 catheters every 30 min during 2 consecutive meal intervals. Blood samples were immediately placed in heparinized tubes on ice and kept chilled until processed. For plasma, blood was centrifuged within $1 \mathrm{hr}$ after sampling for $12 \mathrm{~min}$ at $1,854 \times \mathrm{g}$ and $4^{\circ} \mathrm{C}$. Plasma for folates and glucose and whole blood for VFA determinations were kept frozen at $-20^{\circ} \mathrm{C}$ until assayed. For lactate and BHBA determinations, blood was immediately deproteinized and $0.9 \mathrm{~mL}$ of distilled water and $100 \mu \mathrm{L}$ of $6 N$ perchloric acid were added to $1 \mathrm{~mL}$ of blood. The tubes were mixed thoroughly and left on ice for at least $2 \mathrm{~h}$. The tubes were then centrifuged for $30 \mathrm{~min}$ at $31,000 \times \mathrm{g}$. Supernatant was collected and immediately frozen at $-20^{\circ} \mathrm{C}$ until assayed.

Rumen fluid was collected every $60 \mathrm{~min}$ during 2 meal intervals through the ruminal cannula with a 120 $\mathrm{mL}$ syringe screwed to a stainless tube ending with a fine metal mesh (RT Rumen Fluid Collection Tube, Bar Diamond Inc., Parma, ID) and oriented toward the center of the rumen. The $\mathrm{pH}$ was recorded immediately and then the fluid was acidified by mixing $10 \mathrm{~mL}$ of 1 $M \mathrm{H}_{2} \mathrm{SO}_{4}$ with $90 \mathrm{~mL}$ of ruminal fluid and immediately 
frozen at $-20^{\circ} \mathrm{C}$ until assayed. Osmolality was determined by freezing point depression (Osmometer 3W2, Advanced Instruments Inc., Norwood, MA).

Folates in plasma and rumen fluid were determined in duplicate by radioassay with a commercial kit (Quantaphase Folates, Bio-Rad Laboratories Ltd., Mississauga, Ontario, Canada) as described by Girard and Matte (1988) and Girard et al. (1994). Plasma glucose, blood BHBA, and lactate were determined using commercial kits (Glucose, Roche Diagnostics GmbH, Mannheim, Germany, and \#310-uv and \#826-A, Sigma Diagnostics, Oakville, Ontario, Canada, respectively. Blood acetate, propionate, and butyrate were determined according to Reynolds et al. (1986). On the day of sampling, concentrations of ammonia in rumen fluid and urea-N and ammonia in fresh blood were measured with an automatic analyzer (Technicon Autoanalyzer II, Technicon Instruments Corp., Tarrytown, NY) as described previously (Huntington, 1984). Blood hemoglobin was determined colorimetrically using cyanmethemoglobin as the standard (Manet, 1969). Packed cell volume was determined on fresh samples by microcentrifugation of capillary tubes.

Blood flow in the right ruminal artery was recorded continuously from $15 \mathrm{~min}$ before the first sampling time to 15 min after the last sample was taken.

Microbial counts were carried out on rumen fluid samples collected $2 \mathrm{~h}$ after the distribution of the meal for 2 feeding cycles. Total viable counts and cellulolytic bacteria were determined according to the methods described by Chiquette et al. (1994) and protozoa were determined according to Imai et al. (1989).

\section{Calculations and Statistical Analysis}

The net flux of nutrients across the rumen wall drained by the right ruminal vein was calculated as described by Girard et al. (2001) for each sampling time. A positive net flux indicates a release of a nutrient from the rumen wall whereas a negative flux indicates an uptake. Statistical analyses for arterial concentrations, net flux of nutrients across the rumen wall, ruminal concentrations, and microbial counts were conducted on postprandial values that were averaged across 2 feeding cycles.

Average milk production and DMI during the last week of the experiment, milk composition and milk component yields, and microbial counts were analyzed using the MIXED procedure of SAS (SAS Institute, 2004) according to an unbalanced crossover design with cows, treatments, and periods as main effects.

Ruminal and arterial concentrations and net flux of nutrients across the rumen wall were analyzed using the MIXED procedure of SAS (SAS Institute, 2004) according to an unbalanced crossover design with cows, periods, and treatments as main effects, and repeated measures in time. Because the time intervals were equal, the 2 following covariance structures were compared: compound symmetry and first-order autoregressive. For each variable, the statistical analysis retained was the one with the smallest fit statistic values. When the treatment effects reached a level of significance of $90 \%$, orthogonal contrasts (linear, quadratic) were compared. Results are reported as least squares means and standard errors of the means. The significance level was defined at $P \leq 0.05$ and trends toward significance were considered at $0.05<P<0.10$.

\section{RESULTS}

Dietary supplements of folic acid had no effect $(P$ $\geq 0.14$ ) on milk production or DMI (Table 2). Milk concentrations and yields of total solids, fat, and CP increased linearly $(P \leq 0.04)$ with the dose of folic acid ingested (Table 2). Supplementary folic acid had no effect $(P \geq 0.12)$ on concentrations or yields of ash and lactose in milk. Concentrations of folates in milk were not affected $(P=0.24)$ by dietary supplements of folic acid but the amount of folates secreted daily in milk tended $(P=0.10)$ to increase linearly $(P=0.04)$ with the dose ingested.

Concentrations of ruminal folates, averaged over time, increased linearly $(P \leq 0.001)$ with the dose of folic acid ingested but the response of ruminal concentrations of folates to folic acid supplementation varied according to postprandial times (Figure 1; treatment $\times$ time, $P \leq 0.001)$. Ruminal concentrations of butyrate decreased quadratically $(P=0.02)$ with the daily supply in folic acid (Table 3). Dietary folic acid supplementation had no effect $(P \geq 0.34)$, however, on $\mathrm{pH}$ or osmolality of ruminal fluid; ruminal concentrations of lactate, ammonia, acetate, propionate, or total VFA; acetate:propionate ratio; or microbial counts (Table 3). Ruminal concentrations of lactate, ammonia, and VFA as well as $\mathrm{pH}$ and osmolality in ruminal fluid changed with time $(P \leq 0.02)$, the highest concentrations being observed between 60 and 120 min after the meal. Folic acid supplementation increased arterial concentrations of folates (linear effect, $P=0.0002$; Table 4).

Blood flow in the right ruminal artery was not affected $(P=0.3)$ by the treatments (Table 5$)$. However, it changed $(P \leq 0.001)$ according to postprandial time: 98, 109, 105, 100, 99, 98, and 96 (SEM 3) L/h at 0, 30, $60,90,120,150$, and $180 \mathrm{~min}$ after the meal, respectively. The net flux of folates across the rumen wall was not affected $(P=0.72$; Table 5$)$ by the dietary supplements of folic acid and it was not different from zero $(P$ $\geq 0.3$; Figure 2 ). The uptake of urea- $\mathrm{N}$ by the rumen 


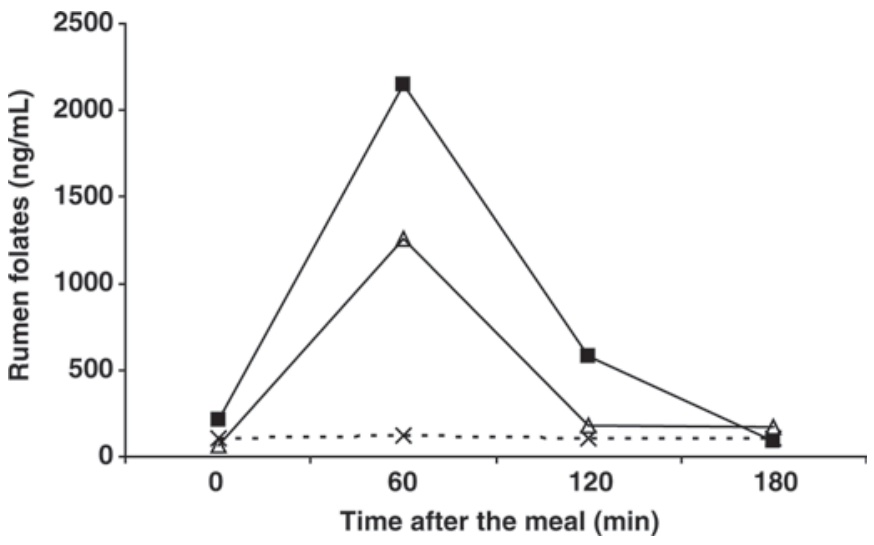

Figure 1. Folate concentrations in ruminal fluid of cows fed daily 0 $(--\times--), 3(-\Delta-)$, or $6(-\mathbf{-}-) \mathrm{mg}$ of folic acid per $\mathrm{kg}$ of BW (SEM $=191$; supplement by time interaction, $P=0.001$ ). Differences among treatments were significant only $60 \mathrm{~min}$ after the meal, with $P$-values of $0.85,0.0001,0.19$, and 0.94 at $0,60,120$, and $180 \mathrm{~min}$ after the meal, respectively.

wall tended to increase $(P=0.09$, quadratic effect $P=$ 0.04 ) with an augmentation of the dose ingested (Table $5)$. Net fluxes of other nutrients across the ruminal wall were not affected $(P \geq 0.3)$ by folic acid supplements (Table 5). The net flux of ammonia across the rumen wall increased until 60 min after the meal to reach a plateau, and it decreased progressively after $90 \mathrm{~min}$ postprandial (time effect, $P=0.001$ ). Uptake of urea-N by the rumen wall followed the opposite pattern (time effect, $P=0.04$ ). The net flux of all VFA increased until 60 min after the meal and decreased progressively thereafter (time effect, $P \leq 0.0001$ ).

\section{DISCUSSION}

In the present study, milk yields of total solids, fat, and protein increased linearly with increasing amounts of folic acid ingested without affecting DMI as previously observed in multiparous cows (Girard et al., 1995; Girard and Matte, 1998; Graulet et al., 2007).

Comparing the same levels of folic acid supplementation, Girard et al. (2005) observed that milk concentrations of folates increased quadratically with the dose of folic acid ingested, the highest concentrations being observed with $3 \mathrm{mg}$ per $\mathrm{kg}$ of BW per d (Girard et al., 2005). In the present study, although milk concentrations of folates were numerically higher in cows fed folic acid supplements, this difference was not statistically significant. Only the amounts of folates secreted in milk per day tended to increase with the amounts of folic acid ingested.

Ingestion of supplementary folic acid increased folate concentrations in the rumen fluid as previously observed in steers by Girard et al. (1994). However, in the present study, concentrations of folates in ruminal fluid of unsupplemented cows were 2 times higher than the concentrations reported by Girard et al. (1994) for unsupplemented steers (107 vs. $50 \mathrm{ng} / \mathrm{mL}$ ). This difference was likely caused by the methods used for sample preparation. In the study by Girard et al. (1994), ruminal fluid of steers was centrifuged to remove all cells whereas, in the present experiment, ruminal fluid was directly acidified. Santschi et al. (2005b) observed that folate concentration is higher in acidified than in centrifuged rumen fluid, demonstrating that, in animals fed no folic acid supplement, the vitamin is mostly present

Table 2. Effects of dietary supplement of folic acid on DMI, milk production, and milk composition of dairy cows $(\mathrm{n}=5)$

\begin{tabular}{|c|c|c|c|c|c|}
\hline \multirow[b]{2}{*}{ Item } & \multicolumn{3}{|c|}{ Folic acid supplement (mg/kg of BW per d) } & \multirow[b]{2}{*}{ SEM } & \multirow[b]{2}{*}{$P$-value } \\
\hline & 0 & 3 & 6 & & \\
\hline Milk production $(\mathrm{kg} / \mathrm{d})$ & 25.9 & 27.0 & 28.7 & 0.8 & 0.14 \\
\hline DMI $(\mathrm{kg} / \mathrm{d})$ & 20.0 & 18.9 & 20.6 & 1.5 & 0.70 \\
\hline \multicolumn{6}{|l|}{ Milk composition } \\
\hline Total solids $(\mathrm{g} / \mathrm{kg})$ & 114.8 & 121.5 & 125.9 & 1.7 & $0.01^{1}$ \\
\hline Fat $(\mathrm{g} / \mathrm{kg})$ & 33.3 & 39.1 & 41.2 & 1.9 & $0.07^{1}$ \\
\hline $\mathrm{CP}(\mathrm{g} / \mathrm{kg})$ & 29.9 & 30.8 & 32.1 & 0.5 & $0.09^{1}$ \\
\hline Ash $(\mathrm{g} / \mathrm{kg})$ & 6.7 & 6.7 & 6.7 & 0.1 & 0.94 \\
\hline Lactose $^{2}(\mathrm{~g} / \mathrm{kg})$ & 44.9 & 44.9 & 45.8 & 0.7 & 0.59 \\
\hline \multicolumn{6}{|l|}{ Milk yields } \\
\hline Total solids $(\mathrm{kg} / \mathrm{d})$ & 2.95 & 3.25 & 3.63 & 0.11 & $0.02^{1}$ \\
\hline Fat $(\mathrm{kg} / \mathrm{d})$ & 0.85 & 1.03 & 1.19 & 0.06 & $0.02^{1}$ \\
\hline $\mathrm{CP}(\mathrm{kg} / \mathrm{d})$ & 0.77 & 0.83 & 0.92 & 0.03 & $0.04^{1}$ \\
\hline $\operatorname{Ash}(\mathrm{kg} / \mathrm{d})$ & 0.17 & 0.18 & 0.19 & 0.01 & 0.12 \\
\hline $\operatorname{Lactose}^{2}(\mathrm{~kg} / \mathrm{d})$ & 1.16 & 1.21 & 1.32 & 0.05 & 0.19 \\
\hline Milk folates $(\mathrm{ng} / \mathrm{mL})$ & 36.4 & 44.0 & 46.1 & 3.6 & 0.24 \\
\hline Milk folates $(\mathrm{mg} / \mathrm{d})$ & 0.93 & 1.19 & 1.36 & 0.11 & $0.10^{1}$ \\
\hline
\end{tabular}


Table 3. Effects of dietary supplement of folic acid on nutrient concentrations in ruminal fluid $(\mathrm{n}=5)$

\begin{tabular}{|c|c|c|c|c|c|c|c|}
\hline Item & \multicolumn{3}{|c|}{ Folic acid supplement (mg/kg of BW per d) } & SEM & \multicolumn{3}{|c|}{$P$-value } \\
\hline $\mathrm{pH}$ & 6.53 & 6.51 & 6.55 & 0.05 & 0.78 & $<0.0001$ & 0.48 \\
\hline Lactate $(\mathrm{m} M)$ & 0.27 & 0.22 & 0.18 & 0.16 & 0.94 & 0.02 & 0.98 \\
\hline Ammonia $(\mathrm{m} M)$ & 4.40 & 3.71 & 4.32 & 0.35 & 0.34 & $<0.0001$ & 0.31 \\
\hline \multicolumn{8}{|l|}{ Volatile fatty acids } \\
\hline Butyrate $(\mathrm{m} M)^{1}$ & 11.5 & 9.9 & 10.9 & 0.4 & 0.05 & $<0.0001$ & 0.27 \\
\hline Total $(\mathrm{m} M)$ & 101.6 & 93.3 & 95.0 & 4.4 & 0.43 & 0.0003 & 0.17 \\
\hline $\mathrm{C} 2: \mathrm{C} 3$ & 3.61 & 3.67 & 3.64 & 0.13 & 0.79 & $<0.0001$ & 0.22 \\
\hline Total viable cells ${ }^{2}\left(\times 10^{9} / \mathrm{mL}\right)$ & 0.96 & 0.96 & 0.99 & 0.17 & 0.99 & - & - \\
\hline Cellulolytic cells ${ }^{2}\left(\times 10^{7} / \mathrm{mL}\right)^{\prime}$ & 12.1 & 12.8 & 10.7 & 4.1 & 0.93 & - & - \\
\hline Protozoa $^{2}\left(\times 10^{5} / \mathrm{mL}\right)$ & 4.4 & 3.9 & 3.5 & 0.8 & 0.79 & - & - \\
\hline
\end{tabular}

${ }^{1}$ Quadratic effect of supplements; $P=0.02$.

${ }^{2}$ Measured on samples collected $2 \mathrm{~h}$ postmeal only.

Table 4. Effects of dietary supplement of folic acid on arterial concentrations of nutrients $(\mathrm{n}=5)$

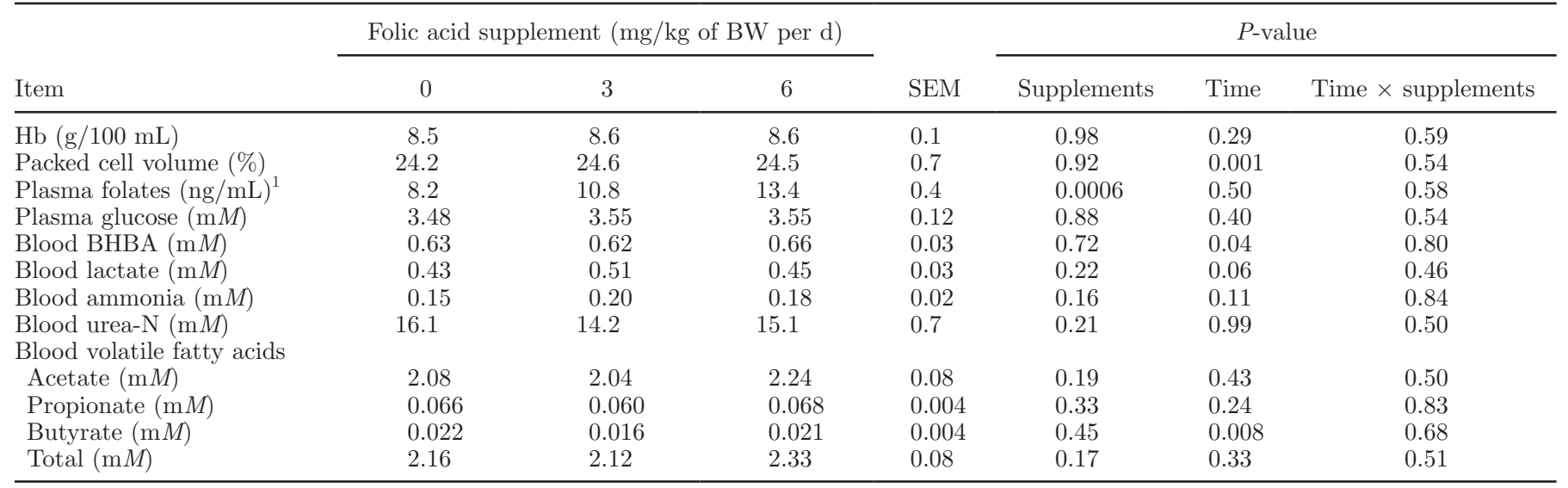

${ }^{1}$ Linear effect of supplements; $P \leq 0.02$.

Table 5. Effects of dietary supplements of folic acid on blood flow in the right ruminal artery and net flux of nutrients across the right ruminal wall $(\mathrm{n}=5)$

\begin{tabular}{|c|c|c|c|c|c|c|c|}
\hline \multirow[b]{2}{*}{ Item } & \multicolumn{3}{|c|}{ Folic acid supplement $(\mathrm{mg} / \mathrm{kg}$ of $\mathrm{BW}$ per $\mathrm{d})$} & \multirow[b]{2}{*}{ SEM } & \multicolumn{3}{|c|}{$P$-value } \\
\hline & 0 & 3 & 6 & & Supplements & Time & Time $\times$ supplements \\
\hline Plasma glucose $(\mathrm{mmol} / \mathrm{h})$ & -4.3 & -4.3 & -5.0 & 1.0 & 0.85 & 0.90 & 0.16 \\
\hline Blood BHBA (mmol/h) & 22.4 & 24.8 & 26.2 & 1.5 & 0.30 & 0.78 & 0.86 \\
\hline Blood lactate $(\mathrm{mmol} / \mathrm{h})$ & 13.1 & 10.3 & 13.6 & 1.7 & 0.35 & 0.28 & 0.71 \\
\hline \multicolumn{8}{|l|}{ Blood volatile fatty acids } \\
\hline Acetate $(\mathrm{mmol} / \mathrm{h})$ & 399.1 & 327.4 & 317.3 & 47.5 & 0.50 & $<0.0001$ & 0.79 \\
\hline Propionate $(\mathrm{mmol} / \mathrm{h})$ & 113.5 & 99.5 & 95.3 & 13.0 & 0.64 & $<0.0001$ & 0.87 \\
\hline Butyrate $(\mathrm{mmol} / \mathrm{h})$ & 17.9 & 14.8 & 10.5 & 3.6 & 0.42 & $<0.0001$ & 0.91 \\
\hline Total $(\mathrm{mmol} / \mathrm{h})$ & 530.5 & 441.7 & 423.1 & 63.7 & 0.52 & $<0.0001$ & 0.88 \\
\hline
\end{tabular}

${ }^{1}$ Quadratic effect of supplements; $P=0.04$. 
within bacteria and is released upon bacteria lysis under the action of acid.

Plasma arterial concentrations of folates increased linearly with the amounts of vitamin ingested as previously reported (Girard and Matte, 1998; Girard et al., 2005). However, the flux of folates across the rumen wall was not affected by the dietary supplements of folic acid and this flux was not different from zero. Plasma arterial concentrations of folates were correlated with the vitamin concentrations in the rumen fluid $(\mathrm{r}=0.34$, $P=0.0008)$ but there was no significant correlation between folate concentrations in rumen fluid and the net flux of the vitamin across the rumen wall $(\mathrm{r}=0.17$, $P=0.20)$. Girard et al. (2001) observed a net release of folates across the rumen wall of dairy cows during the first 20 min following a single injection in the rumen of $2.5 \mathrm{~g}$ of folic acid. In the present study, the smaller doses of folic acid ingested per meal (approximately $0.2-0.5 \mathrm{~g})$ as well as the lower frequency of sampling (every $30 \mathrm{~min}$ ) could explain the lack of detection of folate flux across the rumen wall even when the cows were fed folic acid supplements.

Although in vitro studies indicate that some ruminal microorganisms, especially cellulolytic ones, have requirements for folic acid (Hall et al., 1955; Slyter and Weaver, 1977; Wejdemar, 1996), there were no marked effects of dietary supplements of folic acid on ruminal fermentation in the present experiment. Ingestion of daily supplements of folic acid had limited effects on ruminal fermentation, only decreasing butyrate concentrations in rumen fluid by approximately 5 to $15 \%$. In steers fed diets based on timothy hay and barley, a daily dietary supplement of folic acid $(2 \mathrm{mg} / \mathrm{kg}$ of BW) had no effect on concentrations of acetate and butyrate, DM disappearance in rumen, total-tract DM, $\mathrm{OM}, \mathrm{NDF}, \mathrm{ADF}$ and $\mathrm{CP}$ digestibility, or microbial mass or protein, although it tended to increase concentrations of propionate between 2 and $4 \mathrm{~h}$ after the meal (Chiquette et al., 1993; Girard et al., 1994). This discrepancy could be because of the fact that in a complex environment such as the rumen, requirements of some bacterial populations for the vitamin could have been met by synthesis from other microbial populations.

Dietary supplements of folic acid also had very limited effects on the net flux of nutrients across the rumen wall; only the net uptake of urea- $\mathrm{N}$ by the rumen wall tended to increase when cows were fed supplementary folic acid. Urea transfer to the rumen is inversely related to the concentration of ammonia in rumen and positively related to plasma concentrations of urea (Tan and Murphy, 2004) but neither of these 2 variables was modified by folic acid supplementation in the present experiment. Nevertheless, urea flux across the rumen wall was positively correlated $(\mathrm{r}=0.52, P=$

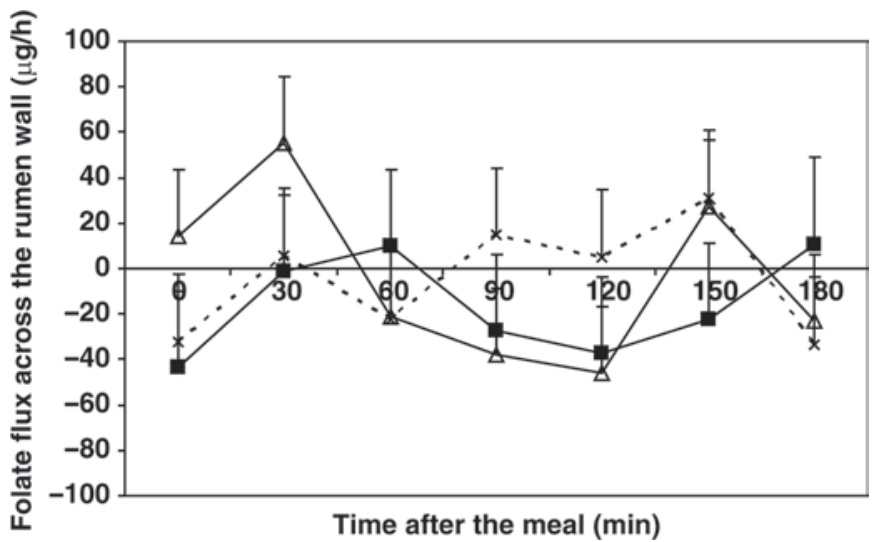

Figure 2. Net flux of folates across the right rumen wall of cows fed daily $0(--\times--), 3(-\Delta-)$, or $6(-\mathbf{\square}-) \mathrm{mg}$ of folic acid per $\mathrm{kg}$ of BW (supplement, $P=0.72$; supplement by time interaction, $P=$ $0.65)$. The net flux of folates across the rumen wall at each time was not different from zero $(P \geq 0.3)$.

0.001) with the arterial concentrations of urea but not correlated with ammonia concentrations in rumen fluid $(\mathrm{r}=0.09, P=0.49)$.

\section{CONCLUSIONS}

Dietary supplements of folic acid increased ruminal and plasma concentrations of folates but no flux of folates was detected across the rumen wall. Milk yields of total solids, fat, and CP increased linearly with the dose of folic acid ingested, although supplementary folic acid had limited effect on ruminal concentrations of VFA and ammonia and on net flux of nutrients across the rumen wall. Although net flux of nutrients across the total digestive tract was not measured, these observations suggest that the effects of the folic acid supplementation on lactational performance cannot be explained by effects on ruminal microflora or rumen fermentation.

\section{ACKNOWLEDGMENTS}

The authors acknowledge the Dairy Farmers of Canada (Ottawa, Ontario, Canada) and the Matching Investment Initiative of Agriculture and Agri-Food Canada (Ottawa, Ontario, Canada) for financial support. The authors are also grateful to Chrystiane Plante and Liette Veilleux for technical assistance and Steve Méthot for statistical advice (all at Agriculture and Agri-Food Canada, Sherbrooke, Québec, Canada).

\section{REFERENCES}

Agriculture Canada. 1990. Recommended Code of Practice for Care and Handling of Dairy Cattle. Publ. No. 1853/E. Agriculture Canada, Ottawa, Ontario, Canada. 
Association of Official Analytical Chemists. 2000. Official Methods of Analysis. 17th ed. AOAC, Arlington, VA.

Canadian Council on Animal Care. 1993. Guide to the Care and Use of Experimental Animals, 2nd ed. Vol. 1. E. D. Rolfert, B. M. Cross, and A. A. McWilliam, ed. Canadian Council on Animal Care, Ottawa, Ontario, Canada.

Chiquette, J., C. L. Girard, and J. J. Matte. 1993. Effect of diet and folic acid addition on digestibility and ruminal fermentation on growing steers. J. Anim. Sci. 71:2793-2798.

Chiquette, J., P. Savoie, and A. Lirette. 1994. Effects of maceration at mowing on digestibility and ruminal fermentation of timothy hay in steers. Can. J. Anim. Sci. 74:235-242.

Girard, C. L., J. Chiquette, and J. J. Matte. 1994. Concentrations of folates in ruminal content of steers: Responses to a dietary supplement of folic acid in relation with the nature of the diet. J. Anim. Sci. 72:1023-1028.

Girard, C. L., H. Lapierre, A. Desrochers, C. Benchaar, J. J. Matte, and D. Rémond. 2001. Net flux of folates and vitamin $B_{12}$ through the gastrointestinal tract and the liver of lactating dairy cows. Br. J. Nutr. 86:707-715.

Girard, C. L., H. Lapierre, J. J. Matte, and G. E. Lobley. 2005. Effects of dietary supplements of folic acid and rumen-protected methionine on lactational performance and folate metabolism of dairy cows. J. Dairy Sci. 88:660-670.

Girard, C. L., and J. J. Matte. 1988. Blood serum concentrations of folates and vitamin $\mathrm{B}_{12}$ during growth period of white veal calves. Can. J. Anim. Sci. 68:455-460.

Girard, C. L., and J. J. Matte. 1998. Dietary supplements of folic acid during lactation: Effects on the performance of dairy cows. J. Dairy Sci. 81:1412-1419.

Girard, C. L., J. J. Matte, and G. F. Tremblay. 1995. Gestation and lactation of dairy cows: A role for folic acid? J. Dairy Sci. 78:404411.

Graulet, B., J. J. Matte, A. Desrochers, L. Doepel, M. F. Palin, and C. L. Girard. 2007. Effects of dietary supplements of folic acid and vitamin $\mathrm{B}_{12}$ on metabolism of dairy cows in early lactation. J. Dairy Sci. 90:3442-3455.

Hall, G., E. W. Cheng, and W. Burroughs. 1955. B-vitamins stimulatory to cellulose digestion by washed suspensions of rumen microorganisms. Proc. Iowa Acad. Sci. 62:273-278.

Huntington, G. B. 1984. Net absorption of glucose and nitrogenous compounds by lactating Holstein cows. J. Dairy Sci. 67:19191927.
Imai, S., S. Han, K. J. Chen, and H. Kudu. 1989. Composition of the rumen ciliate population in experimental herds of cattle and sheep in Lethbridge, Alberta, Western Canada. Can. J. Microbiol. $35: 686-690$

Manet, L. 1969. Techniques usuelles de biologie clinique. Page 39 in Hématologie. Éditions Médicales Flammarion. Paris, France.

National Research Council. 2001. Nutrient Requirements of Dairy Cattle. 7th rev. ed. Natl. Acad. Sci., Washington, DC.

Rémond, D., C. Poncet, and J. Lefaivre. 1993. Technical note: Ruminal vein catheterization and continuous blood flow measurement in ruminal arteries of sheep. J. Anim. Sci. 71:1276-1280.

Reynolds, P. J., G. B. Huntington, and C. K. Reynolds. 1986. Determination of volatile fatty acids, lactate, and $\beta$-hydroxybutyrate in blood by ion exchange clean-up and gas chromatography. J. Anim. Sci. 63(Suppl. 1):424.

Santschi, D. E., R. Berthiaume, J. J. Matte, A. F. Mustafa, and C. L. Girard. 2005a. Fate of supplementary B-vitamins in the gastrointestinal tract of dairy cows. J. Dairy Sci. 88:2043-2054.

Santschi, D. E., J. Chiquette, R. Berthiaume, J. J. Matte, A. F. Mustafa, and C. L. Girard. 2005b. Effects of methods of collection and sample preparation on the concentrations of B-vitamins in ruminal fluid of dairy cows. Can. J. Anim. Sci. 85:417-420.

SAS Institute. 2004. SAS/STAT User's Guide. Volumes 1-7. SAS Institute Inc., Cary, NC.

Schwab, E. C., C. G. Schwab, R. D. Shaver, C. L. Girard, D. E. Putnam, and N. L. Whitehouse. 2006. Dietary forage and nonfiber carbohydrate contents influence B-vitamin intake, duodenal flow, and apparent ruminal synthesis in lactating dairy cows. J. Dairy Sci. 89:174-187.

Slyter, L. L., and J. M. Weaver. 1977. Tetrahydrofolate and other growth requirements of certain strains of Ruminococcus flavefaciens. Appl. Environ. Microbiol. 33:363-369.

Tan, Z., and M. R. Murphy. 2004. Ammonia production, ammonia absorption, and urea recycling in ruminants. A review. J. Anim. Feed Sci. 13:389-404.

Wejdemar, K. 1996. Some factors stimulating the growth of Butyrivibrio fibrisolvens TC33 in clarified rumen fluid. Swedish J. Agric. Res. 26:11-18. 